\title{
Seasonal lipid storage as overwintering strategy of Antarctic krill
}

\author{
Wilhelm Hagen ${ }^{1}$, Edward S. Van Vleet ${ }^{2}$, Gerhard Kattner ${ }^{3}$ \\ ${ }^{2}$ Institut für Polarökologie, Universität Kiel, Wischhofstrasse 1-3, Geb. 12, D-24148 Kiel, Germany \\ ${ }^{2}$ Marine Science Department, University of South Florida, 140 Seventh Avenue South, St. Petersburg, Florida 33701 , USA \\ ${ }^{3}$ Alired-Wegener-Institut für Polar- und Meeresforschung, Postfach 120161, D-27515 Bremerhaven, Germany
}

\begin{abstract}
Conflicting hypotheses prevail on the overwintering strategies of the Antarctic krill Euphausia superba due to the difficult accessibility of Antarctic waters, especlally in winter, and hence, to the lack of seasonal data. This study reports on the seasonal lipid dynamics of E. superba (25 to $56 \mathrm{~mm}$ ) collected in the Weddell Sea in late winter/spring, summer, autumn and mid-winter. Total lipid data provide evidence of large seasonal accumulation of reserve lipids in austral summer with a mean lipid content of $28.2 \%$ of dry mass and particularly in autumn, when mean lipid levels peak with $39.2 \%$ of dry mass. After the overwintering period mean lipid contents decrease to a minumum of $10.5 \%$ of dry mass, indicating extensive utilisation of lipid reserves during winter. These data suggest that lipids contribute significantly to the overwinterng success of this extremely versatile species. Lipid class analyses of spring and summer specimens $(10$ to $56 \mathrm{~mm}$ ) from the Antarctic Peninsula and the Weddell Sea revealed that not only triacylglycerol, but also phosphatidylcholine may serve as important storage lipids of E. superba. In the other dominant Antarctic krill species, E. crystallorophias (10 to $40 \mathrm{~mm}$ ) and Thysanoessa macrura (10 to $27 \mathrm{~mm}$ ), wax esters are the primary depot lipid, but phosphatidylcholine also functions as a storage lipid in these species. Phosphatidylcholine is unusual as a reserve lipid, being an essential component of biomembranes. In contrast, phosphatidylethanolamine, the other major phospholipid class, seems to have exclusively membrane functions, since it does not increase (in percent of dry mass) with increasing lipid levels in these 3 euphausiid species.
\end{abstract}

KEY WORDS: Antarctic krill - Euphausia superba Euphausia crystallorophias Thysanoessa macrura Lipid content and composition - Energy reserve - Overwintering

\section{INTRODUCTION}

Euphausia superba is one of the key species in the Southern Ocean food web with biomass estimates of hundreds of millions of tons (Miller \& Hampton 1989). Due to its overwhelming dominance in some Antarctic regions and its potential commercial interest, marine research has focused on the biology of the Antarctic krill. However, the mysteries of its fascinating life history have only recently started to unravel, partially with the help of powerful ice-breaking research vessels. Apart from other open questions such as longevity and production of krill, one of the major enigmas has concerned the overwintering strategy of E. superba. As

·E-mail:npf11@rz.uni-kiel.d400.de a predominantly herbivorous pelagic species with a high energy throughput (Kils 1981), krill has to face an extended period of food paucity during the long Antarctic winter and early spring period, when phytoplankton is at a minimum (Scharek et al, 1994). Experimental evidence of starved summer specimens has indicated protein catabolism and body shrinkage along with lowered metabolic rates as possible survival mechanisms (Ikeda \& Dixon 1982). Energy-saving reduction of metabolic activity has also been measured in winter specimens (Kawaguchi et al. 1986, Quetin \& Ross 1991, Torres et al. 1994a). Investigations by divers and remotely operated vehicles have revealed that krill may convert to a 'pseudobenthic' mode of life during winter, when it inhabits near-surface ice crevices to find refuge from predators and to feed on ice algae 
(Kottmeier \& Sullivan 1987, O'Brien 1987, Marschall 1988, Stretch et al. 1988). Omnivory, and hence utilisation of alternative food sources such as detritus or metazoans, has also been suggested as a strategy to avoid starvation during the dark season (Clarke 1980 , Kawaguchi et al. 1986, Price et al. 1988, Daly \& Macaulay 1991, Huntley et al. 1994)

Reliance of Euphausia superba on lipid reserves to survive the winter period has been disputed in the past, largely based on summer lipid data and starvation experiments (Ikeda \& Dixon 1982, Clarke 1984). However, Hagen (1988) and Quetin et al. (1994) have suggested that lipids are used as an energy reserve during winter. Quetin \& Ross (1991) calculated that lipids provide only $11 \%$ of the energy for successful overwintering (vs $71 \%$ of the energy saved in winter by metabolic reduction). Another recent comparison of krill lipid contents from fall and winter produced somewhat conflicting evidence of lipid storage due to differences between open water and pack ice sampling sites as well as high individual variability (Torres et al. 1994b). The latter study as well as earlier starvation experiments have shown that krill may survive up to 211 d without food (Ikeda \& Dixon 1982, Torres et al. 1994 b). However, according to calculations by Ikeda \& Dixon (1982), proteins contribute most of the energy during this starvation period. Obviously, there is an urgent need for lipid data of krill, especially from the non-summer periods. We have therefore compiled a large seasonal data set to shed new light on the role of lipids in the overwintering of Antarctic krill, which is still not unequivocally clarified.

\section{MATERIALS AND METHODS}

During 'Polarstern' expeditions in summer 1985, midwinter 1986, late winter/spring 1986, and autumn 1992 , krill specimens were collected in the southeastern Weddell Sea between $68^{\circ}$ and $76^{\circ} \mathrm{S}$; only the midwinter samples are from $62^{\circ}$ to $64^{\circ} \mathrm{S}$. Juvenile to adult Euphausja superba (25 to $56 \mathrm{~mm}$ ) were sampled by different plankton and nekton nets for the determination of their total lipid content. The specimens were sorted in a cooling container to species, size and sex and frozen individually in glass vials at $-80^{\circ} \mathrm{C}$. In the home laboratory dry mass was measured after lyophilisation for $48 \mathrm{~h}$. Total lipids were extracted with dichloromethane:methanol $(2: 1, v: v$, with $0.01 \%$ butylhydroxytoluene added as antioxidant). The lipid content was determined gravimetrically, essentially after Folch et al. (1957). The total lipid contents are expressed in percent of dry mass (\% DM).

For the lipid class determinations, larval to adult specimens of Euphausia superba with a size of 10 to
$56 \mathrm{~mm}$ were sampled to cover a wider range of ontogenetic stages. The specimens were obtained during spring $1983\left(60^{\circ}\right.$ to $\left.63^{\circ} \mathrm{S}\right)$ and summer 1985 off the Antarctic Peninsula $\left(60^{\circ}\right.$ to $\left.63^{\circ} \mathrm{S}\right)$ and during summer 1985 in the Weddell Sea $\left(70^{\circ}\right.$ to $\left.74^{\circ} \mathrm{S}\right)$, using the same procedures as for the total lipid samples. E. crystallorophias specimens (10 to $40 \mathrm{~mm}$ ) were collected during summer 1985 in the southeastern Weddell Sea $\left(70^{\circ}\right.$ to $\left.78^{\circ} \mathrm{S}\right)$. Thysanoessa macrura specimens $(10$ to $27 \mathrm{~mm}$ ) were sampled during spring 1983 and summer 1985 near the Antarctic Peninsula $\left(60^{\circ}\right.$ to $\left.61^{\circ} \mathrm{S}\right)$ and during summer 1985 in the southeastern Weddell Sea $\left(72^{\circ}\right.$ to $\left.73^{\circ} \mathrm{S}\right)$. The lipid class compositions were analysed on an Iatroscan Mark II using thin-layer chromatography combined with a flame-ionisation detector according to the method of Fraser et al. (1985). Different standard mixtures were prepared for calibration, which approximated the lipid class compositions of the analysed samples. For details see Hagen (1988).

\section{RESULTS AND DISCUSSION}

Fig. 1 shows the seasonal lipid dynamics of juvenile to adult Euphausia superba in the Weddell Sea. Maximum lipid contents are accumulated in autumn with a mean of $39.2 \pm 5.6 \%$ DM ( $n=65)$, whereas in spring lipid levels reach a minimum averaging $10.5 \pm 4.0 \%$ $\mathrm{DM}(\mathrm{n}=71)$. Intermediate and more variable lipid contents occurred during summer $(28.2 \pm 6.9 \% \mathrm{DM}, \mathrm{n}=$ 23). These data clearly demonstrate the accumulation of extensive lipid reserves by $E$. superba during the productive season to a maximum in autumn (April/ May), and they show the depletion of these energy reserves during the winter to a minimum in early

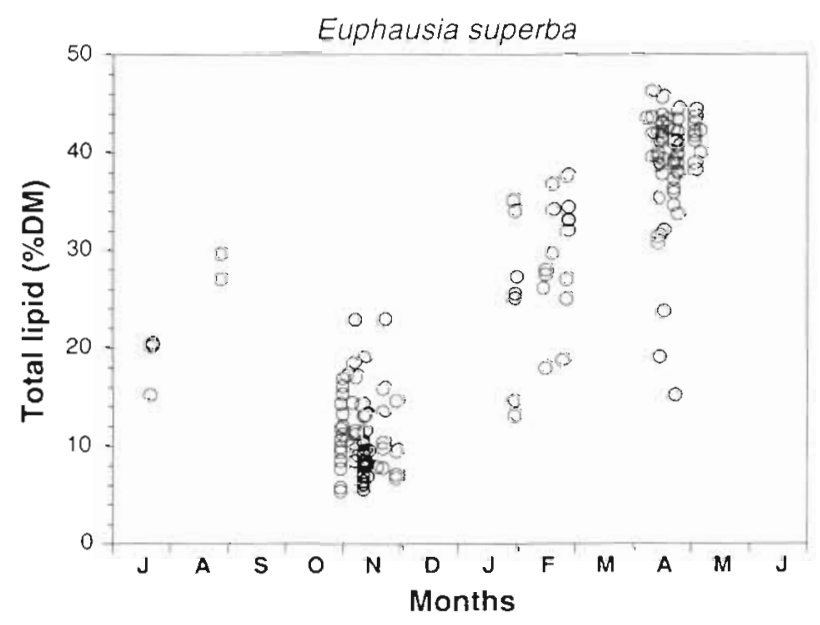

Fig. 1. Euphausia superba (25 to $56 \mathrm{~mm} ; \mathrm{n}=164)$. Seasonal lipid accumulation and depletion of juvenile to adult krill specimens in the southeastern Weddell Sea 
spring (November), before the onset of substantial phytoplankton growth (Scharek et al. 1994).

We could not detect significant sex-dependent differences within seasons, although we ascribe the higher variability of lipid data during summer to reproductive processes. In contrast to the other dominant Antarctic euphausiids, Euphausia crystallorophias and Thysanoessa macrura, which spawn in spring (Littlepage 1964, Makarov 1979, authors' pers. obs.), reproduction in E. superba can extend from November to April with major spawning activities in January and February (summer) (Mauchline 1980, Quetin et al. 1994). In the southeastern Weddell Sea the onset of spawning is delayed and extends over a short period from early January to early March (Spiridonov 1995). The large amounts of first calyptopis larvae in this high Antarctic region in mid-February during our 1985 expedition (Hagen 1988) also showed that spawning must have taken place around mid-January.

In October/November 1986 in the southeastern Weddell Sea the ovaries of Euphausia superba were still immature and had not developed further from the winter resting stage (V. Siegel pers. comm.). According to Couzin-Roudy (1993) egg production is restricted to the summer in E. superba. Hence, reproductive processes seem to be largely fuelled by phytoplanktonic input in late spring and summer and do not explain the extensive lipid utilisation during winter/spring down to a quarter of the maximum lipid levels. This strong dependence on internal resources corroborates the poor feeding conditions in winter. Based on reduced respiration rates of adult krill under winter conditions (Quetin \& Ross 1991) and safe keeping $5 \%$ DM essential lipids, a rough calculation shows that the autumn lipid reserves can provide metabolic energy for about 5 mo. By means of metabolic reduction and the efficient utilisation of its energy reserves, E. superba seems to be able to survive the winter period and with the support of ice algae in early spring (Marschall 1988, Smetacek et al. 1990) krill should be able to reach the onset of phytoplankton production in November.

Lipids of Euphausia superba have been analysed in great detail and triacylglycerols have been identified as the principal storage lipid class (e.g. Clarke 1980 , 1984, Hagen 1988, Pond et al. 1995). For E. superba and the North Atlantic euphausiids Thysanoessa raschii and $T$. inermis it has been suggested that in addition to triacylglycerols or wax esters, the usual depot lipids, phospholipids may also serve as storage lipid (Saether et al. 1985, 1986). Normally, phospholipids are essential components of biomembranes and typically do not serve as storage lipids.

Our data on the lipid composition of Euphausia superba clearly show a linear increase of triacylglyc-



Fig. 2. Euphausia superba (10 to $56 \mathrm{~mm} ; \mathrm{n}=59$ ) from the Antarctic Peninsula and the Weddell Sea. Linear accumulation curves of triacylglycerol and phosphatidylcholine, indicating the function of both lipid classes as depot lipids, in contrast to phosphatidylethanolamine. INote that the amount of the different lipid classes is expressed in percent of total dry mass in order to show the accumulation of triacylglycerol and phosphatidylcholine with increasing total lipid content (\% DM), irrespective of size or mass of the specimens]

erol and phosphatidylcholine (in percent of dry mass) with increasing lipid levels, which results in very large amounts of these lipid classes in the lipid-rich specimens (Fig. 2). Fig. 2 also demonstrates that only 1 specific phospholipid class is the responsible component of this accumulation, namely phosphatidylcholine, bet ter known as lecithin. This selective accumulation of an individual phospholipid with increasing lipid levels strongly suggests its function as an energy reserve. However, triacylglycerol is the primary depot lipid and is deposited at a faster rate (steeper slope) than phosphatidylcholine. In contrast, the percentage of the other major phospholipid, phosphatidylethanolamine. does not increase (in percent of dry mass) with increasing total lipid content, similar to cholesterol (Hagen 1988). This disproves the function of phosphatidylethanolamine as a reserve lipid. In E. crystallorophias as well as in Thysanoessa macrura phosphatidylcholine also serves as depot lipid, in addition to wax esters (Fig. 3). In spite of marked regional, seasonal and ontogenetic differences, all these lipid data follow the same relationships along linear accumulation curves, indicating a basic underlying biochemical process in lipid deposition and mobilisation. They may even serve as 'calibration curves', since we can quantify the major lipid class fractions, if we know the total lipid content of a specimen.

The increase of phosphatidylcholine with increasing lipid levels cannot be explained by the formation of additional membrane compounds during this process, 



Fig. 3. (A) Euphausia crystallorophias (10 to $40 \mathrm{~mm}_{i} \mathrm{n}=50$ ) from the Weddell Sea and (B) Thysanoessa macrura 10 to $27 \mathrm{~mm} ; \mathrm{n}=28$ ) from the Antarctic Peninsula and the Weddell Sea. Linear accumulation curves of wax ester and phosphatidylcholine indicate the function of both lipid classes as

depot lipids, in contrast to phosphatidylethanolamine

due to the large amounts of phosphatidylcholine accumulated. On the other hand, body shrinkage during times of starvation would also not lead to such a remarkable decrease in phosphatidylcholine. In spite of extensive lipid analyses the function of phosphatidylcholine as an important storage lipid could not be verified for any of the other Antarctic zooplankton taxa investigated (Hagen 1988). Such a phenomenon has so far only been observed in euphausiids. Why these euphausiids also deposit phosphatidylcholine as energy reserve is still an unresolved question. It has been hypothesised that phospholipids are more easily mobilised than neutral lipids (Saether et al. 1986). Generally, we have no satisfying physiological or biochemical answers to the selective accumulation of different lipid classes, such as triacylglycerol, wax ester or phosphatidylcholine, in marine organisms (Clarke 1983, Hagen et al. 1993, 1995).
In conclusion, our data demonstrate the importance of extensive lipid reserves, triacylglycerol and phosphatidylcholine, for Euphausia superba to survive the Antarctic winter. On the other hand, E. crystallorophias and Thysanoessa macrura make use of wax esters and phosphatidylcholine as energy reserves. The seasonal lipid accumulation of E. superba during the productive period and consumption during winter/spring before the phytoplankton bloom is much more pronounced than previously assumed. The substantial lipid deposition of this dominant biomass species will also have strong implications on the overall biogenic energy flux in Antarctic waters, since part of the intense but short seasonal pelagic primary production is conserved in the pelagial as chemical energy and made available to other trophic levels over a very prolonged time period.

Acknowledgements. We thank especially Elke Mizdalski and Dr Sigrid Schnack-Schiel as well as the captains, crew and colleagues for support during the 'Polarstern' cruises. We are grateful to Dr Nicolai Mumm for collection of mid-winter samples and to Holger Auel for assistance with the extractions. Dr Volker Siegel provided unpublished data on the sexual maturity of krill from the Weddell Sea. Prof. Gotthilf Hempel and Prof Michael Splndler made constructive suggestions on the manuscript. W.H. is indebted to Prof. John Sargent and his team for introducing him to analytical methods in lipid biochemistry. This study was partially supported by the 'Deutsche Forschungsgemeinschaft' and the 'National Science Foundation' (DPP-8614029). This is Contribution no. 949 of the Alfred-Wegener-Institut für Polar- und Meeresforschung.

\section{LITERATURE CITED}

Clarke A (1980) The biochemical composition of krill, Euphausia superba Dana, from South Georgia. J Exp Mar Biol Ecol 43:221-236

Clarke A (1983) Life in cold water: the physiological ecology of polar marine ectotherms. Oceanogr Mar Biol A Rev 21: $341-453$

Clarke A (1984) Lipid content and composition of Antarctic krill, Euphausia superba Dana. J Crust Biol 4:285-294

Couzin-Roudy J (1993) Reproductive strategies of the Mediterranean krill, Meganyctiphanes norvegica and the Antarctic krill, Euphausia superba (Crustacea: Euphausiacea). Invertebr Reprod Dev 23:105-114

Daly KL, Macaulay MC (1991) Influence of physical and biological mesoscale dynamics on the seasonal distribution and behavior of Euphausia superba in the antarctic marginal ice zone. Mar Ecol Prog Ser 79:37-66

Folch J, Lees M, Sloane-Stanley GH (1957) A simple method for the isolation and purification of total lipides from animal tissues. J Biol Chem 226:497-509

Fraser AJ, Tocher DR, Sargent JR (1985) Thin-layer chromatography-flame ionization detection and the quantitation of marine neutral lipids and phospholipids. J Exp Mar Biol Ecol 88:91-100

Hagen W (1988) Zur Bedeutung der Lipide im antarktischen Zooplankton. Ber Polarforsch 49:1-129 (English version 
1989: On the significance of lipids in Antarctic zooplankton. Can Trans Fish Aquat Sci 5458:1-149)

Hagen W, Kattner G, Graeve M (1993) Calanoides acutus and Calanus propinquus, Antarctic copepods with different lipid storage modes via wax esters or triacylglycerols. Mar Ecol Prog Ser 97:135-142

Hagen W, Kattner G, Graeve M (1995) On the lipid biochemistry of polar copepods: compositional differences in the Antarctic calanoids Euchaeta antarctica and Euchirella rostromagna. Mar Biol 123:451-457

Huntley ME, Nordhausen W, Lopez MDG (1994) Elemental composition, metabolic activity and growth of Antarctic krill Euphausia superba during winter. Mar Ecol Prog Ser $107: 23-40$

Ikeda T, Dixon P (1982) Body shrinkage as a possible overwintering mechanism of the antarctic krill Euphausia superba Dana. J Exp Mar Biol Ecol 62:143-151

Kawaguchı K, Ishikawa S, Matsuda O (1986) The overwintering strategy of Antarctic krill (Euphausia superba Dana) under the coastal fast ice off the Ongul Islands in LützowHolm Bay. Mem Natl Inst Polar Res Spec Iss 44:67-85

Kils U (1981) Swimming behaviour, swimming performance and energy balance of Antarctic krill Euphausia superba. BIOMASS Sci Ser 3:1-122.

Kottmeier ST, Sullivan CW (1987) Late winter primary production in sea ice and seawater west of the Antarctic Peninsula. Mar Ecol Prog Ser 36:287-298

Littlepage $J$ (1964) Seasonal variation in lipid content of two Antarctic marine Crustacea. In: Carrick R, Holdgate MW, Prévost J (eds) Biologie antarctique. Hermann, Paris, p $463-470$

Makarov RR (1979) Larval distribution and reproductive ecology of Thysanoessa macrura (Crustacea: Euphausiacea) in the Scotia Sea. Mar Biol 52:377-386

Marschall HP (1988) The overwintering strategy of Antarctic krill under the pack-ice of the Weddell Sea. Polar Biol 9: $129-135$

Mauchline J (1980) The biology of mysids and euphausiids. Adv Mar Biol 18:1-677

Miller DGM, Hampton I (1989) The biology and ecology of the Antarctic krill (Euphausia superba Dana): a review. BIOMASS Sci Ser 9:1-166

O'Brien DP (1987) Direct observations of the behavior of Euphausia superba and Euphausia crystallorophias (Crus-

This article was submitted to the editor tacea: Euphausiacea) under pack ice during the Antarctic spring of 1985. J Crust Biol 7:437-448

Pond D, Watkins J, Priddle J, Sargent J (1995) Variation in the lipid content and composition of Antarctic krill Euphausia superba at South Georgia. Mar Ecol Prog Ser 117:49-57

Price HJ, Boyd KR, Boyd CM (1988) Omnivorous feeding behavior of the Antarctic krill Euphausia superba. Mar Biol 97:67-77

Quetin LB, Ross RM (1991) Behavioral and physiological characterıstics of the Antarctic krill, Euphausia superba. Am Zool 31:49-63

Quetin LB, Ross RM, Clarke A (1994) Krill energetics: seasonal and environmental aspects of the physiology of Euphausia superba. In: El-Sayed SZ (ed) Southern Ocean ecology: the BIOMASS perspective. Univ Press, Cambridge, p 165-184

Saether O, Ellingsen TE, Mohr $V$ (1985) The distribution of lipid in the tissues of Antarctic krill, Euphausia superba Comp Biochem Physiol 81B: 609-614

Saether O, Ellingsen TE, Mohr V (1986) Lipids of North Atlantic krill. J Lipid Res 27:274-285

Scharek R, Smetacek V, Fahrbach E, Gordon LI, Rohardt G, Moore S (1994) The transition from winter to early spring in the eastern Weddell Sea, Antarctica: plankton biomass and composition in relation to hydrography and nutrients Deep Sea Res 41:1231-1250

Smetacek V, Scharek R, Nöthig EM (1990) Seasonal and regional variation in the pelagial and its relationship to the life history cycle of krill. In: Kerry KR, Hempel G (eds) Antarctic ecosystems: ecological changes and conservation. Springer, Berlin, p 103-114

Spıridonov, VA (1995) Spatial and temporal variability in reproductive timing of Antarctic krill (Euphausia superba Dana\}. Polar Biol 15:161-174

Stretch JJ, Hamner PP, Hamner WM, Michel WC, Cook J, Sullivan CW (1988) Foraging behavior of Antarctic krill Euphausia superba on sea ice microalgae. Mar Ecol Prog Ser 44:131-139

Torres JJ, Aarset AV, Donnelly J, Hopkins TL, Lancraft TM, Ainley DG (1994a) Metabolism of Antarctic micronektonic Crustacea. Mar Ecol Prog Ser 113:207-219

Torres JJ, Donnelly J, Hopkins TL, Lancraft TM, Aarset AV, Ainley DG (1994b) Proximate composition and overwintering strategies of Antarctic micronektonic Crustacea. Mar Ecol Prog Ser 113:221-232

Manuscript first received: June 26, 1995

Revised version accepted: November 15, 1995 